\title{
OPTIMALISASI RANCANGAN SHELL-DAN-TUBE EXCHAGERS (TINJAUAN LITERATUR)
}

(4)

\author{
Muhammad Bakrie $^{1)}$, Muhrinsyah Fatimura ${ }^{2)}$ \\ ${ }^{1,2)}$ Teknik Kimia, Fakultas Teknik, Universitas PGRI Palembang \\ ${ }^{1}$ muhammad.bakrie.mb.@gmail.com, \\ ${ }^{2}$ m.fatimura@univpgri-palembang.ac.id
}

\begin{abstract}
Abstrak
Artikel ini adalah tinjauan literatur rancangan Shell-dan-Tube Heat Exchagers, yang membahas prinsip-prinsip yang mendasari desain heat exchanger, yang mencakup: komponen heat exchanger, klasifikasi menurut konstruksi dan menurut kegunaan, data yang dibutuhkan untuk rancangan termal, rancangan tube side, rancangan shell side, tata letak tube (tube pitch), baffle, dan penurunan tekanan (pressure drop) shellside; dan perbedaan suhu rata-rata, letak fluida pada shellside dan tubeside, penggunaan beberapa shell, dan pada design. Tujuan artikel ini untuk optimalisasi rancang shell dan tube heat exchagers.
\end{abstract}

Kata Kunci : Shell, Tube, heat exchanger, pressure drop, tube pitch, baffle..

\section{PENDAHULUAN}

Heat exchanger adalah alat yang digunakan untuk mentransfer energi panas (entalpi) antara dua atau lebih fluida, antara permukaan padat dan fluida, atau antara partikulat padat dan fluida, pada suhu yang berbeda dan dalam kontak termal. Dalam Heat exchanger, biasanya tidak ada panas eksternal dan interaksi bekerja. Aplikasi tipikal melibatkan pemanasan atau pendinginan aliran fluida yang menjadi perhatian dan penguapan atau kondensasi aliran fluida komponen tunggal atau Multi komponen. Dalam aplikasi lain, tujuannya mungkin untuk merecovery (memulihkan) atau melepaskan panas, atau mensterilkan, mempasteurisasi, fraksinasi, distilasi, konsentrasikan, kristalisasi, atau kontrol fluida proses. Pembakaran dan reaksi kimia dapat terjadi di dalam exchanger, seperti di dalam boiler, pemanas yang dibakar, dan penukar fluidized-bed. Perangkat mekanis dapat digunakan di beberapa penukar seperti bejana yang diaduk, dan reaktor tangki berpengaduk. Dalam heat exchanger, pipa panas tidak hanya bertindak sebagai dinding pemisah, tetapi juga memfasilitasi perpindahan panas dengan kondensasi, penguapan, dan konduksi fluida kerja di dalam pipa panas. Secara umum, jika cairan tidak dapat bercampur, dinding pemisah dapat dihilangkan, dan antarmuka di antaranya cairan menggantikan permukaan perpindahan panas, seperti dalam penukar panas kontak langsung. Penukar panas terdiri dari panas elemen transfer seperti inti atau matriks yang mengandung permukaan perpindahan panas, dan elemen distribusi fluida seperti itu sebagai header, manifold, tank, nosel atau pipa saluran masuk dan keluar, atau segel. Biasanya tidak ada bagian yang bergerak dalam heat exchanger, namun, ada pengecualian, seperti penukar regeneratif berputar (di mana matriksnya berada digerakkan secara mekanis untuk berputar pada kecepatan desain tertentu). (Charate, 2015 dan Nimankar, 2016) 


\section{TATA NAMA KOMPONEN HEAT EXCHANGER}

Untuk tujuan menetapkan terminologi standar, Gambar 1 mengilustrasikan berbagai jenis penukar panas. bagian dan sambungan khusus, untuk tujuan ilustrasi saja, diberi nomor untuk identifikasi pada seperti pada Tabel 1. (TEMA, 1999)

Tabel 1. Tatanama Komponen Heat Exchanger

\begin{tabular}{|c|c|c|c|}
\hline No & Nama & No & Nama \\
\hline 1 & Stationery Head-Channel & 21 & Floating Head Cover-External \\
\hline 2 & Stationery Head-Bonnet & 22 & Floating Tubesheet Skirt \\
\hline 3 & Stationery Head Flange- & 23 & Packing Box \\
\hline 4 & Channel Cover & 24 & Packing \\
\hline 5 & Stationery Head Nozze & 25 & Packing Gland \\
\hline 6 & Stationery Tubesheet & 26 & Lantern Ring \\
\hline 7 & Tubes & 27 & Tierods and Spancers \\
\hline 8 & Shell & 28 & Transverse Baffles or Support Plates \\
\hline 9 & Shell Cover & 29 & Impingement Plate \\
\hline 10 & Shell Flange-Stationery Head 1 & 30 & Longitudinal Baffle \\
\hline 11 & Shell Flange-Rear Head End & 31 & Pass Partition \\
\hline & & & $\Rightarrow$ \\
\hline 12 & Shell Nozzel & 32 & Vent Connection \\
\hline 13 & Shell Cover Flange & 33 & Drain Connection \\
\hline 14 & Expansion Joint & 34 & Instrument Connection \\
\hline 15 & Floating Tubesheet & 35 & Support Saddle \\
\hline 16 & Floating Head Cover & 36 & Lifting Lug \\
\hline 17 & Floating Head Cover Flange & 37 & Support Bracket \\
\hline 18 & Floating Head Backing Device & 38 & Weir \\
\hline 19 & Split Shear Ring & 39 & Liquid Level Connectoion \\
\hline 20 & Slip-on Backing Flange & 40 & Floating Head Support \\
\hline
\end{tabular}




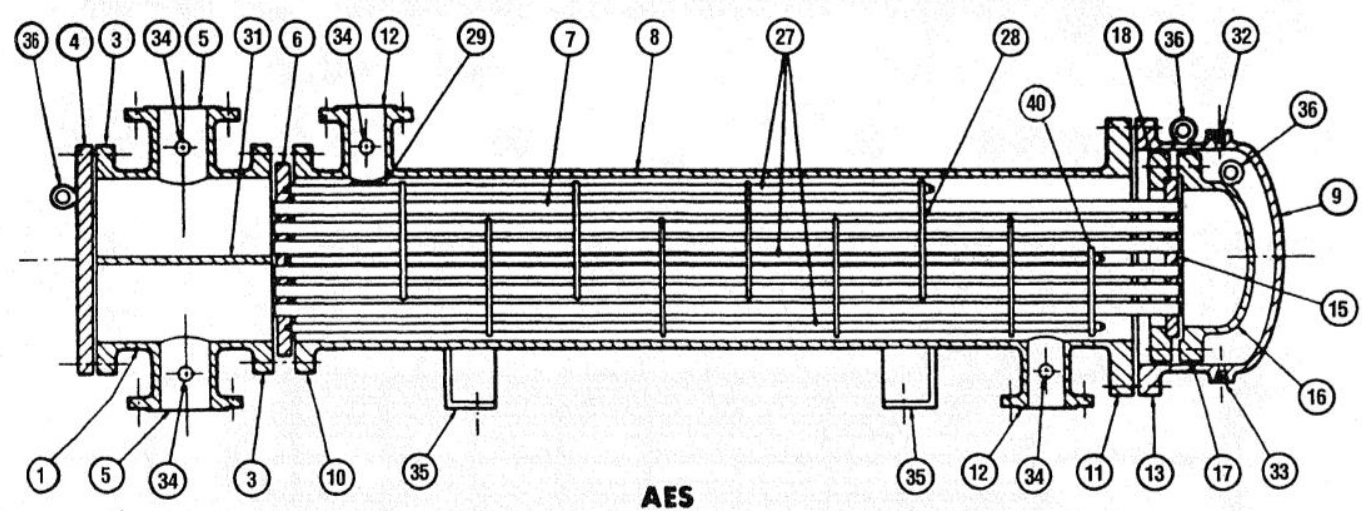

Gambar 1. Komponen Heat Exchanger

\section{KOMPONEN SHELL-DAN-TUBE HEAT EXCHAGERS}

Saat ini penukar panas shell dan tube adalah jenis penukar panas yang paling umum digunakan secara luas di kilang minyak dan proses kimia besar lainnya, karena sesuai dengan aplikasi tekanan tinggi. (Samal, 2013) Penukar panas shell dan tube adalah juga banyak digunakan di berbagai industri karena mudah dalam perawatan dan biaya rendah. (Nimankar, 2016)

Menurut The Standards of the Tubular Exchanger Manufacturers Association (TEMA), Shell-danTube Heat Exchagers dibagi menjadi tiga bagian yaitu: kepala depan (front head), shell, dan kepala belakang (rear head). TEMA memberikan berbagai kemungkinan konstruksi exchanger seperti diberikan pada Gambar 2, yaitu penukar BEL memiliki penutup depan, shell dua lintasan dengan buffle longitudinal (two-pass shell with a longitudinal baffle), dan bagian belakang tube tetap (fixed-tubesheet rear head). Jenis Rancangan shell-and-tube heat exchanger, seperti pada diberikan Gambar 2 adalah: (TEMA, 1999) 


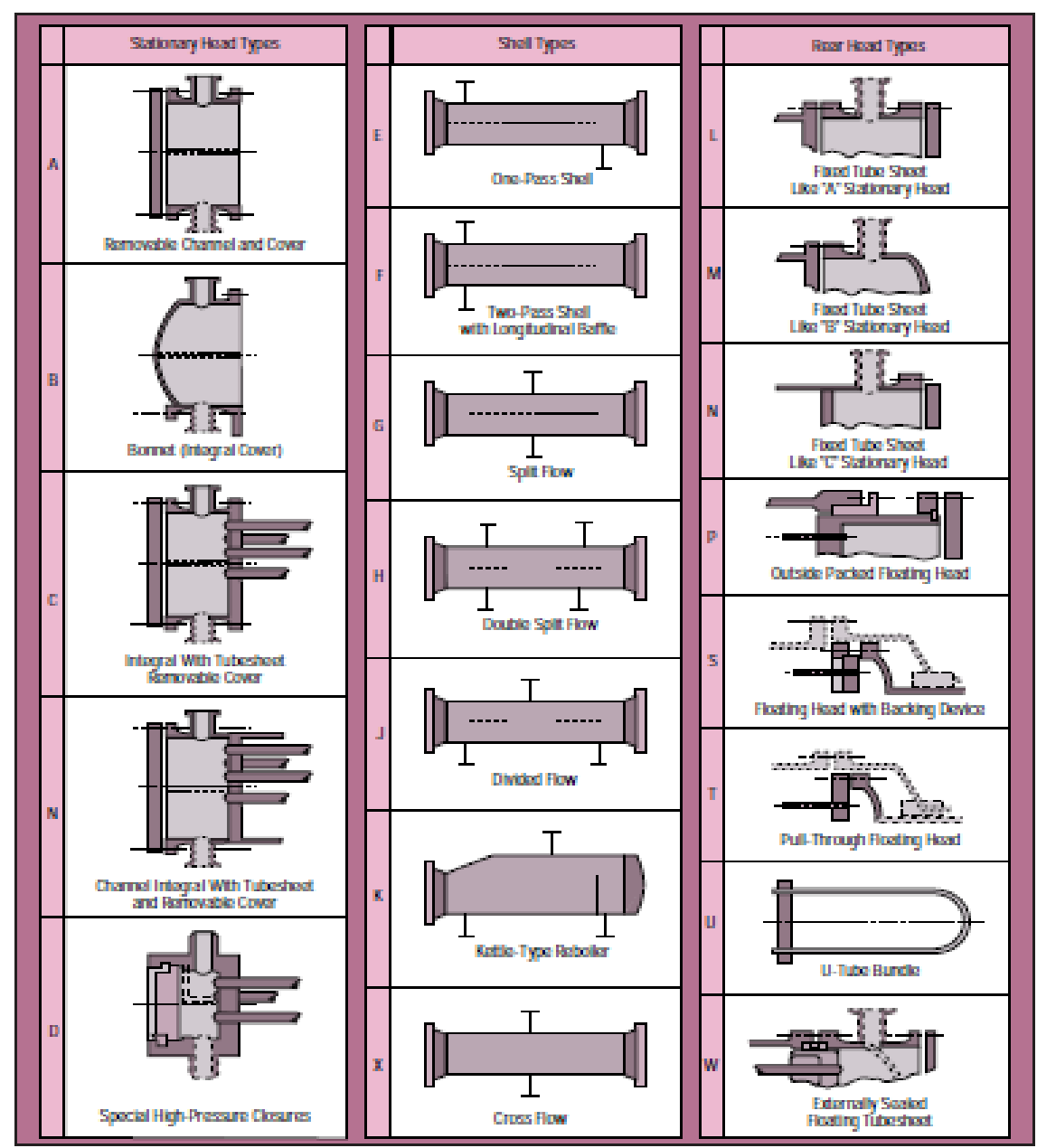

Gambar 2. Rancangan shell-and-tube heat exchanger (TEMA, 1999)

Jenis kepala stationeri:

a. Saluran dan penutup yang dapat dilepas, A

b. Bonnet (penutup bulat), B

c. Perangkat tutup tubesheet removable, $\mathrm{C}$

d. Perangkat saluran dengan tubesheet dan penutup yang dapat dilepas, $\mathrm{N}$

e. Penutupan bertekanan tinggi khusus, D

Jenis shell:

a. Shell one-pass, E

b. Shell dua lintasan dengan baffle longitudinal, F

c. Aliran split, $\mathrm{G}$

d. Aliran split ganda, $\mathrm{H}$

e. Arus terbagi, J

f. Reboiler jenis ketel, $\mathrm{K}$

g. Arus silang, $\mathrm{X}$

Jenis kepala belakang:

a. Tubesheet tetap seperti kepala stasioner "A", I

b. Tubesheet tetap seperti kepala stasioner "B", M 
c. Tubesheet tetap seperti kepala stasioner "C", N

d. Kepala mengambang kikemas luar, $\mathrm{P}$

e. Kepala mengambang dengan perangkat pendukung, $\mathrm{S}$

f. Kepala mengambang tarik, $\mathrm{T}$

g. Bundel $U$-Tube, $\mathrm{U}$

h. Tubesheet apung tersegel secara eksternal, W

\section{KLASIFIKASI BERDASARKAN KONSTRUKSI}

\section{Tubesheet Tetap}

Penukar panas tube-tube tetap memiliki tube lurus yang dikunci di kedua ujungnya ke tubesheet yang dilas ke shell (Gambar 3). Konstruksi mungkin memiliki penutup saluran yang dapat dilepas (misalnya $A E L$ ), penutup saluran tipe kap (misalnya, $B E M$ ), atau tubesheet bulat (misalnya, $N E N$ ).

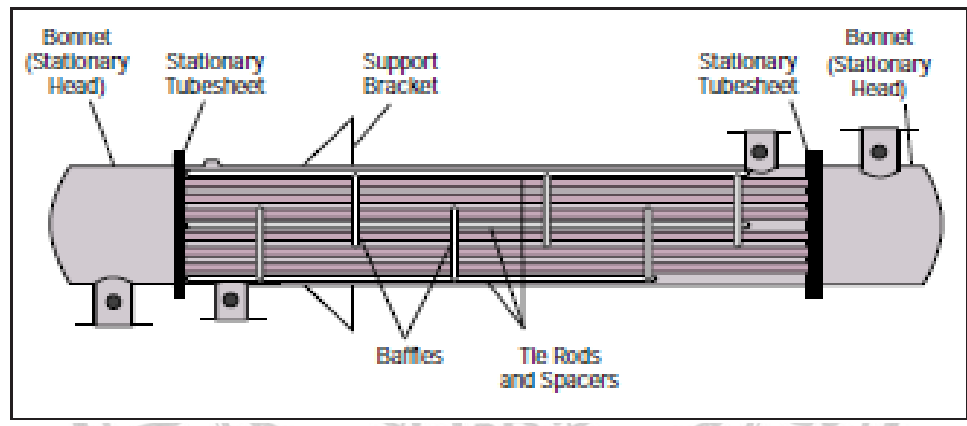

Gambar 3. Heat exchanger tubesheet-tetap

Keuntungan utama dari konstruksi fixed tubesheet adalah biayanya yang rendah karena konstruksinya yang sederhana. Faktanya, tubesheet tetap adalah jenis konstruksi yang paling murah, selama tidak diperlukan sambungan ekspansi. Keuntungan lainnya adalah tube dapat dibersihkan secara mekanis setelah pelepasan penutup saluran atau tutup shell, dan kebocoran cairan shellside menjadi minimal karena tidak ada sambungan. Kerugian dari desain ini adalah karena bundel dipasang pada shell dan tidak dapat dilepas, bagian luar tube tidak dapat dibersihkan secara mekanis. Jadi, aplikasinya terbatas pada penggunaan shellside bersih. Namun, jika program pembersihan bahan kimia yang memuaskan dapat digunakan, konstruksi tubesheet tetap dapat dipilih untuk penggunaan shellside kotor. Jika terjadi perbedaan suhu yang besar antara tube dan shell, tubesheet tidak akan dapat menyerap tegangan diferensial, sehingga perlu untuk menggabungkan sambungan ekspansi. Ini menghilangkan sebagian besar keuntungan dari biaya rendah. (Mukherjee, 1998)

\section{U-tube}

Sesuai dengan namanya, tube penukar kalor tube-U (Gambar 4) ditekuk dalam bentuk U. Hanya ada satu lembar tube dalam penukar panas $U$-tube . Namun, biaya yang lebih rendah untuk lembaran tube tunggal diimbangi oleh biaya tambahan yang dikeluarkan untuk pembengkokan tube dan diameter shell yang agak lebih besar (karena radius tikungan-U minimum), membuat biaya penukar panas tube$U$ sebanding dengan penukar sheet-tube tetap. 


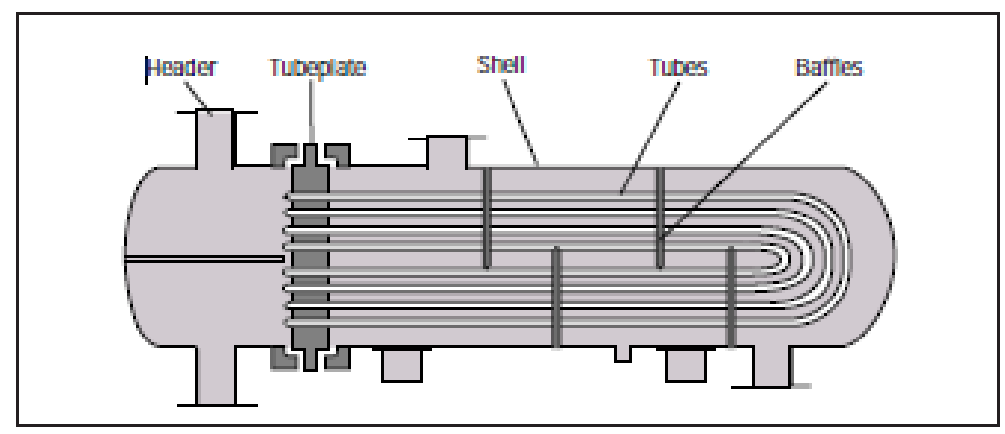

Gambar 4. Tube-U Heat exchanger

Keuntungan dari Heat exchanger tipe tube- $U$ adalah karena salah satu ujungnya bebas, bundel dapat mengembang atau berkontraksi sebagai respons terhadap perbedaan tegangan. Selain itu, bagian luar tube dapat dibersihkan, karena bundel tube dapat dilepas. Kerugian dari konstruksi tube- $U$ adalah bahwa bagian dalam tube tidak dapat dibersihkan secara efektif, karena tikungan-U akan membutuhkan lobang bor fleksibel untuk pembersihan. Dengan demikian, penukar panas tube- $U$ tidak boleh digunakan untuk layanan dengan cairan kotor di dalam tube. (Mukherjee, 1998)

\section{Kepala Mengambang (Floating Head)}

Penukar panas kepala apung adalah jenis sell tube heat eexchanger yang paling serbaguna, dan juga yang paling mahal. Dalam desain ini, satu sheet tube dipasang relatif terhadap shell, dan yang lainnya bebas untuk "mengapung" di dalam shell. Hal ini memungkinkan perluasan bundel tube secara bebas, serta pembersihan bagian dalam dan luar tube. Dengan demikian, sell tube heat eexchanger kepala apung dapat digunakan untuk fluida sisi shellnya dan sisi tubenya kotor menjadikannya jenis kostruksi standar yang digunakan dalam layanan kotor, seperti di penyulingan minyak bumi. Ada berbagai jenis konstruksi kepala apung. Dua paling banyak yang umum adalah desain memakai saluran (pull-through) dengan peralatan pendukung (TEMA S) dan pull-through (TEMA T).

Desain TEMA S (Gambar 5) adalah konfigurasi yang paling umum dalam industri proses kimia (CPI). Penutup kepala terapung diamankan pada tubesheet apung dengan mebautnya ke cincin pendukung split. Penutup kepala apung ini terletak di luar ujung shell dan ditutup oleh penutup shell dengan diameter lebih besar. Untuk membongkar penukar panas, penutup shell dilepas terlebih dahulu, kemudian cincin pendukung terpisah, dan kemudian penutup kepala mengambang, setelah itu bundel tube dapat dilepas dari ujung stasioner.

Dalam konstruksi TEMA T (Gambar 6), seluruh bundel tube, termasuk rakitan kepala apung, dapat dilepas dari ujung stasioner, karena diameter shell lebih besar dari flens kepala apung. Penutup kepala apung dibaut langsung ke tubesheet apung sehingga cincin pendukung terpisah tidak diperlukan.

Keuntungan dari konstruksi ini adalah bundel tube dapat dikeluarkan dari shell tanpa melepaskan shell atau penutup kepala apung, sehingga mengurangi waktu perawatan. rancangan ini sangat cocok untuk reboiler ketel yang memiliki media pemanas kotor di mana tube- $U$ tidak dapat digunakan. Karena shell yang membesar, konstruksi ini memiliki biaya tertinggi dari semua jenis penukar panas. 
Ada juga dua jenis konstruksi kepala apung yang dikemas - kotak isian yang dikemas luar (TEMA P) dan cincin lentera yang dikemas di luar (TEMA W) (lihat Gambar 2). Namun, karena rentan terhadap kebocoran, penggunaannya terbatas pada layanan dengan cairan sisi kerang yang tidak berbahaya dan tidak beracun serta memiliki tekanan dan suhu sedang $\left(40 \mathrm{~kg} / \mathrm{cm} 2\right.$ dan $\left.300^{\circ} \mathrm{C}\right)$. ((Mukherjee, 1998, TEMA, 1999)

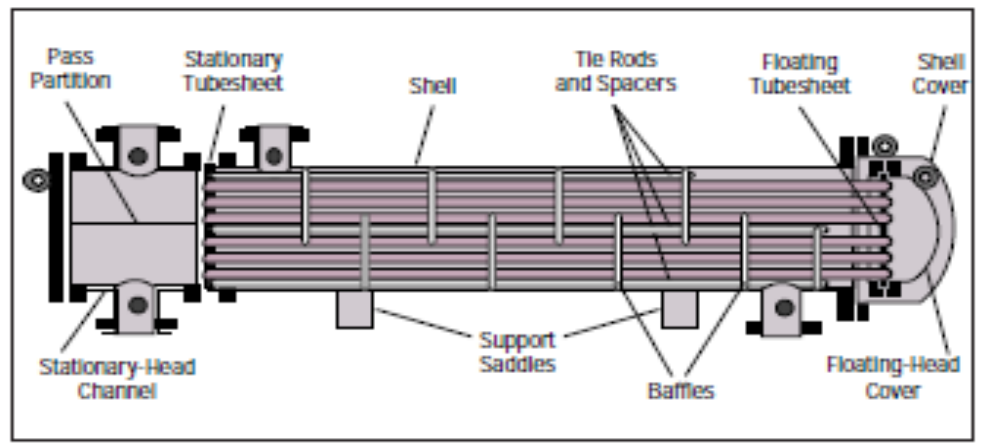

Gambar 5. Penukar kepala mengambang tarik dengan perangkat pendukung (TEMA S)

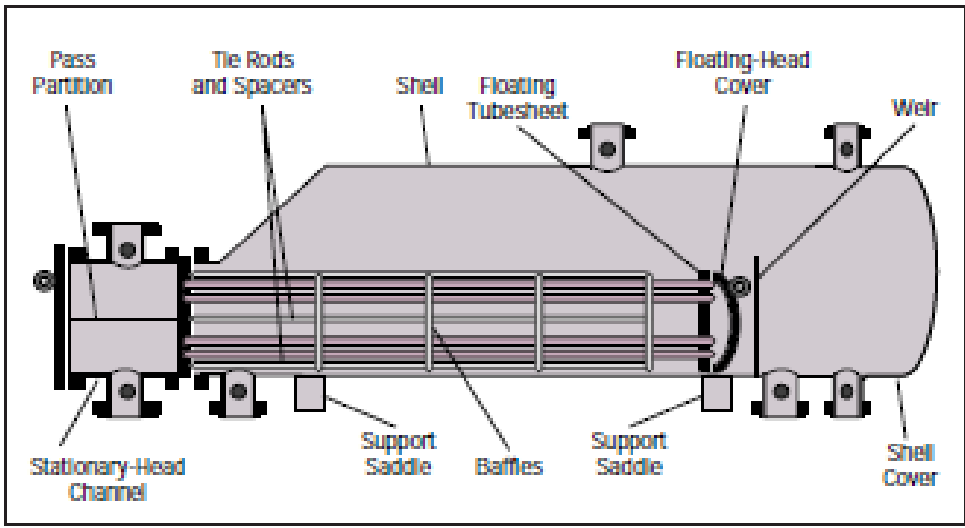

Gambar 6. Penukar kepala mengambang tarik (TEMA T)

\section{Nozzles}

Port masuk dan keluar untuk cairan shell dan tube disebut sebagai nozel, yaitu pipa dengan penampang konstan dilas ke shell dan saluran (channals). Mereka digunakan untuk mendistribusikan atau mengumpulkan cairan secara seragam di shellside dan tubeside. Nozel ini berbeda dengan nosel yang digunakan sebagai perangkat pengukur fluida atau pada mesin jet, yang memiliki variabel luas aliran sepanjang aliran. (Nimankar, 2016)

\section{KLASIFIKASI BERDASARKAN KEGUNAAN}

Pada dasarnya, kegunaan dapat berupa fase tunggal (seperti pendinginan atau pemanasan cairan atau gas) atau dua fase (seperti kondensasi atau penguapan). Karena ada dua sisi dari shell dan tube heat exchanger, ini dapat menyebabkan beberapa kombinasi fungsi.

Secara garis besar, berdasarkan kegunaan heat exchager dapat diklasifikasikan sebagai berikut: (Mukherjee, 1998)

- fase tunggal (baik shellside maupun tubeside); 
- kondensasi (satu sisi kondensasi dan fase tunggal lainnya);

- penguapan (satu sisi menguap dan sisi lain fase tunggal); dan

- kondensasi / penguapan (satu sisi mengembun dan sisi lainnya menguap).

Nomenklatur berikut biasanya digunakan:

Heat exchanger : kedua sisi aliran fase tunggal dan proses (yaitu, bukan utilitas).

Cooler : : satu aliran fluida proses dan yang lainnya air atau udara pendingin.

Pemanas : satu aliran fluida proses dan lainnya aliran panas, seperti uap atau minyak panas.

Kondensor $\quad$ : satu aliran uap kondensasi dan aliran air atau udara pendingin lainnya .

Chiller : satu aliran fluida proses yang dikondensasikan pada suhu sub-atmosfer dan yang lainnya adalah refrigeran mendidih atau aliran proses.

Reboiler : satu aliran aliran dasar dari kolom distilasi dan lainnya aliran air panas (uap atau minyak panas) atau aliran proses.

\section{Data Rancangan}

Data yang harus dilengkapi oleh pemberi lisensi proses sebelum desain dapat dimulai: (Mukherjee, 1998)

1. laju aliran pada kedua saluran.

2. suhu masuk dan keluar dari kedua saluran.

3. tekanan operasi kedua aliran. Ini diperlukan untuk gas, terutama jika massa jenis gas tidak dilengkapi, itu tidak terlalu diperlukan untuk cairan, karena sifatnya tidak berbeda dengan tekanan.

4. penurunan tekanan yang diijinkan untuk kedua aliran. Ini adalah parameter yang sangat penting untuk desain penukar panas. Umumnya, untuk cairan, nilai $0,5-0,7 \mathrm{~kg} / \mathrm{cm} 2$ diperbolehkan per shell. Penurunan tekanan yang lebih tinggi biasanya dijamin untuk cairan kental, terutama di tubeside. Untuk gas, nilai yang diperbolehkan umumnya $0,05-0,2 \mathrm{~kg} / \mathrm{cm} 2$, dengan tipikal 0,1 $\mathrm{kg} / \mathrm{cm} 2$.

5. resistensi fouling untuk kedua aliran. Jika ini tidak dilengkapi, desainer harus mengadopsi nilainilai yang ditentukan dalam standar TEMA atau berdasarkan pengalaman masa lalu.

6. sifat fisik kedua aliran. Ini termasuk viskositas, konduktivitas termal, kerapatan, dan panas spesifik, lebih disukai pada suhu masuk dan keluar. Data viskositas harus disediakan pada suhu masuk dan keluar, terutama untuk cairan, karena variasi suhu mungkin cukup besar dan tidak teratur (baik linier maupun log-log).

7. Beban panas. Tugas yang ditentukan harus konsisten baik untuk shellside maupun tubeside.

8. Jenis penukar panas. Jika tidak dilengkapi perangkat, perancang dapat memilih ini berdasarkan karakteristik dari berbagai jenis konstruksi yang dijelaskan sebelumnya. Nyatanya, designer biasanya berada dalam posisi yang lebih baik daripada insinyur proses untuk melakukan ini.

9. Ukuran saluran. Sebaiknya sesuaikan ukuran nosel dengan ukuran saluran untuk menghindari perluasan atau pereduksi. Namun, kriteria ukuran untuk nozel biasanya lebih ketat daripada saluran, terutama untuk saluran masuk shellside. Akibatnya, ukuran nosel terkadang harus satu ukuran (atau bahkan lebih dalam keadaan luar biasa ) lebih besar dari ukuran saluran yang sesuai, terutama untuk saluran kecil.

10. Ukuran tube yang disukai. Ukuran tube ditetapkan sebagai panjang ketebalan OD. Beberapa pemilik pabrik memiliki ketebalan OD yang disukai (biasanya berdasarkan pertimbangan inventaris), dan area plot yang tersedia akan menentukan panjang tube maksimum. Banyak 
pemilik pabrik lebih suka menstandarisasi ketiga dimensi, sekali lagi berdasarkan pertimbangan inventaris.

11. Diameter shell maksimum. Ini didasarkan pada persyaratan pelepasan bundel tube dan dibatasi oleh kapasitas derek. Batasan tersebut hanya berlaku untuk penukar dengan bundel tube yang dapat dilepas, yaitu tube- $U$ dan kepala-mengambang. Untuk penukar tubesheet tetap, satu satunya batasan adalah kemampuan fabrikasi pabrikan dan ketersediaan komponen seperti dished ujung dan flensa. Dengan demikian, penukar panas floating-head seringkali dibatasi pada shell ID 1,4-1,5 $\mathrm{m}$ dan panjang tube $6 \mathrm{~m}$ atau $9 \mathrm{~m}$, sedangkan penukar panas tube tetap dapat memiliki shell sebesar $3 \mathrm{~m}$ dan panjang tube hingga $12 \mathrm{~m}$ atau lebih.

12. bahan konstruksi. Jika tube dan shell terbuat dari bahan yang sama, semua komponen harus dari bahan ini. Jadi, hanya bahan konstruksi shell and tube perlu ditentukan. Namun, jika shell dan tube memiliki metalurgi yang berbeda, bahan dari semua komponen utama harus ditentukan untuk menghindari ambiguitas. Komponen utama adalah shell (dan penutup shell), tube, saluran (dan penutup saluran), tubesheets, dan baffle. Tube sheet mungkin dilapisi atau dibalut.

13. pertimbangan khusus. Ini termasuk siklus, kondisi gangguan, skenario pengoperasian alternatif, dan apakah pengoperasian terus menerus atau terputus-putus.

\section{DESAIN TUBESIDE}

Tubesheets. Tubesheets (rangkaian tube) digunakan untuk menahan tube pada ujungnya. Tubesheet umumnya adalah pelat logam bundar dengan lubang yang dibor pola tube yang diinginkan, lubang untuk batang pengikat (yang digunakan untuk memberi ruang dan menahan sekat pelat), alur untuk gasket, dan lubang baut untuk flang ke shell dan saluran. Untuk mencegah kebocoran cairan shell di tubesheet melalui celah antara lubang tube dan tube, sambungan tube-ke-tube dibuat dengan banyak metode, seperti memperluas tube, menggulung tube, ekspansi hidrolik tube, pengelasan eksplosif tube, isian sambungan, atau pengelasan atau mematri tube ke tubesheet, sperti pada Gambar 7. (Nimankar, 2016 dan Kern, 1950)

Perhitungan tubeside cukup mudah, karena aliran tubeside merepresentasikan kasus aliran yang sederhana melalui saluran melingkar. Koefisien perpindahan panas dan penurunan tekanan keduanya bervariasi dengan kecepatan sisi tube, yang terakhir lebih kuat. Desain yang baik akan memanfaatkan penurunan tekanan yang diijinkan dengan sebaik-baiknya, karena ini akan menghasilkan koefisien perpindahan panas tertinggi.

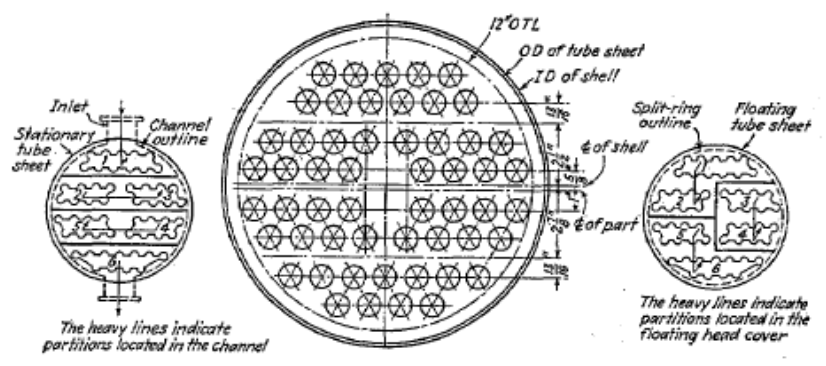

Gambar 7. Tata letak tube-sheet untuk ID shell 13 1/4 -in, ID shell 1 - in dan tube OD 1 11/4 -in.

Tri angular pitc dengan 6 tube passes. (Kern, 1950) 
Jika semua fluida tubeside mengalir melalui semua tube (satu tube pass), itu akan mengarah pada kecepatan tertentu. Biasanya, kecepatan ini sangat rendah dan oleh karena itu harus dinaikkan. Dengan memasukkan pelat partisi laluan (dengan paking yang sesuai) di saluran, fluida sisi tube dibuat untuk mengalir beberapa kali melalui sebagian kecil dari jumlah total tube. Jadi, dalam penukar panas dengan 200 tube dan dua lintasan, fluida mengalir melalui 100 tube sekaligus, dan kecepatannya akan menjadi dua kali lipat jika hanya ada satu lintasan. Jumlah lintasan tube biasanya satu, dua, empat, enam, delapan, dan seterusnya. (Mukherjee, 1998)

\section{KOEFISIEN PERPINDAHAN PANAS}

Koefisien perpindahan panas pada tubeside adalah fungsi dari bilangan Reynolds, bilangan Prandtl, dan diameter tube. Ini dapat dipecah menjadi parameter dasar berikut: sifat fisik (yaitu viskositas, konduktivitas termal, dan panas spesifik); diameter tube; dan, yang paling penting, kecepatan massa.

Variasi viskositas cairan cukup besar; jadi, sifat fisik ini memiliki efek paling dramatis pada koefisien perpindahan panas. Viskositas mempengaruhi koefisien perpindahan panas dalam dua cara yang berlawanan sebagai parameter bilangan Reynolds, dan sebagai parameter bilangan Prandtl. (Mukherjee, 1998)

\section{PENURUNAN TEKANAN (PRESSURE DROP)}

Kecepatan massa sangat mempengaruhi koefisien perpindahan panas. Untuk aliran turbulen, koefisien perpindahan panas sisi tube bervariasi dengan 0,8 kekuatan kecepatan massa tubeside, sedangkan penurunan tekanan tubeside bervariasi dengan kuadrat kecepatan massa. Jadi, dengan bertambahnya kecepatan massa, penurunan tekanan meningkat lebih cepat daripada koefisien perpindahan panas. Karena itu, Akan ada kecepatan massa optimum yang diatasnya akan sia-sia untuk meningkatkan kecepatan massa lebih lanjut. Minimum yang disarankan Kecepatan cairan di dalam tube adalah 1.0 $\mathrm{m} / \mathrm{s}$, sedangkan kecepatan maksimumnya adalah $2.5-3.0 \mathrm{~m} / \mathrm{s}$.

Penurunan tekanan tubeside meningkat tajam dengan peningkatan jumlah tube pass. akibatnya, sering terjadi bahwa untuk sejumlah tube dan dua lintasan, penurunan tekanan jauh lebih rendah dari nilai yang diizinkan, tetapi dengan empat lintasan itu melebihi penurunan tekanan yang diijinkan. Jika dalam keadaan seperti itu tube standar harus digunakan, perancang mungkin terpaksa menerima kecepatan yang agak rendah. Namun, jika diameter dan panjang tube dapat divariasikan, penurunan tekanan yang diijinkan dapat digunakan lebih baik dan kecepatan sisi tube dapat dicapai. (Mukherjee, 1998)

\section{DESAIN SHELLSIDE}

Perhitungan shellside jauh lebih kompleks daripada perhitungan untuk tubeside. Hal ini terutama karena pada shellside tidak hanya ada saluran satu aliran tetapi satu saluran aliran silang utama dan empat aliran kebocoran atau aliran pintas (by pass). Ada berbagai pengaturan aliran shellside, serta berbagai pola tata letak tube dan desain buffle, yang bersama-sama menentukan analisis aliran shellside. 


\section{KONFIGURASI SHELL}

TEMA mendefinisikan berbagai pola shell berdasarkan aliran fluida shellside melalui shell: E, F, G, H, J, K, dan X, lihat Gambar 2. (TEMA, 1999)

Dalam shell single-pass TEMA E, cairan shellside memasuki shell di satu ujung dan keluar dari ujung lainnya. Ini adalah jenis shell yang paling umum lebih banyak penukar panas yang dibuat untuk konfigurasi ini daripada gabungan semua konfigurasi lainnya. Shell dua lintasan TEMA F memiliki sekat longitudinal yang membagi shell menjadi dua lintasan. Cairan shellside masuk di salah satu ujung, melintasi seluruh panjang exchanger melalui satu-setengah luas penampang shell, berbalik dan mengalir melalui celah kedua, lalu akhirnya keluar di ujung jalur kedua. Baffle longitudinal berhenti jauh dari tubesheet, sehingga fluida dapat mengalir ke lintasan kedua. Shell F digunakan untuk situasi lintas suhu yaitu, di mana aliran dingin pergi pada suhu yang lebih tinggi dari suhu outlet aliran panas. Jika shell dua jalur (F) hanya memiliki dua lintasan tube, ini menjadi pengaturan arus berlawanan yang sebenarnya di mana persilangan suhu yang besar dapat dicapai. Shell TEMA G adalah shell split-flow (lihat Gambar 2). Konstruksi ini biasanya digunakan untuk reboiler termosifon horizontal. Hanya ada pelat penyangga pusat dan tidak ada sekat. Kerangka AG tidak dapat digunakan untuk penukar panas dengan panjang tube lebih dari $3 \mathrm{~m}$, karena ini akan melebihi batas maksimum panjang tube tidak didukung yang ditentukan oleh TEMA biasanya 1,5 m, meskipun bervariasi dengan $O D$ tube, ketebalan, dan bahan.

Ketika tube yang lebih panjang dibutuhkan, shell TEMA H (lihat Gambar 2) digunakan. Sebuah shell $\mathrm{H}$ pada dasarnya adalah dua shell $\mathrm{G}$ yang ditempatkan berdampingan, sehingga ada dua pelat pendukung penuh. Ini dijelaskan sebagai konfigurasi pemisahan ganda, karena aliran dibagi dua kali dan digabungkan kembali dua kali. Konstruksi ini, juga, selalu digunakan untuk reboiler termosifon horizontal. The keuntungan dari $\mathrm{G}$ dan $\mathrm{H}$ kerang adalah bahwa penurunan tekanan secara drastis kurang dan tidak ada sekat silang. Shell TEMA J adalah shell/aliran terbagi dimana fluida shellside memasuki shell di tengah dan terbagi menjadi dua bagian, satu mengalir ke kiri dan yang lainnya ke kanan dan pergi secara terpisah. Mereka kemudian digabungkan menjadi satu aliran. Ini diidentifikasi sebagai shell J 1-2. Alternatifnya, aliran dapat dipecah menjadi dua bagian yang memasuki shell di kedua ujungnya, mengalir ke tengah, dan keluar sebagai aliran tunggal, yang diidentifikasi sebagai shell $\mathbf{J} 2-1$.

Shell TEMA X (lihat Gambar 2) adalah shell aliran silang murni di mana cairan sisi shell masuk di bagian atas (atau bawah) shell, mengalir melintasi tube, dan keluar dari sisi shell yang berlawanan. Aliran dapat dimasukkan melalui beberapa nozel yang terletak secara strategis di sepanjang shell untuk mencapai distribusi yang lebih baik. Penurunan tekanan akan sangat rendah pada kenyataannya, hampir tidak ada penurunan tekanan di shell, dan penurunan tekanan yang ada, hampir semuanya ada di nozel. Jadi, konfigurasi ini digunakan untuk mendinginkan atau mengembunkan uap pada tekanan rendah, khususnya vakum. Pelat pendukung penuh dapat ditempatkan jika diperlukan untuk integritas struktural; mereka tidak mengganggu aliran shellside karena sejajar dengan arah aliran. Sebuah shell TEMA K (lihat Gambar 2) adalah shell cross-flow khusus yang digunakan untuk reboiler ketel (dengan demikian K). Ini memiliki ruang pelepasan uap integral yang diwujudkan dalam shell yang diperbesar. Di sini, juga, pelat pendukung penuh dapat digunakan sesuai kebutuhan. 


\section{POLA TATA LETAK TUBE}

Ada empat pola tata letak tube, seperti yang ditunjukkan pada Gambar 8: segitiga (30 ${ }^{\circ}$ ), segitiga diputar $\left(60^{\circ}\right)$, persegi $\left(90^{\circ}\right)$, dan persegi diputar $\left(45^{\circ}\right)$. (Kern, 1950 dan Mukherjee, 1998). Pola segitiga (atau segitiga yang diputar) akan menampung lebih banyak tube daripada pola persegi (atau persegi yang diputar). Selanjutnya, pola segitiga menghasilkan turbulensi yang tinggi dan oleh karena itu menghasilkan koefisien perpindahan panas yang tinggi. Namun, pada pitch tube tipikal 1,25 kali OD tube, itu tidak memungkinkan pembersihan mekanis tube, karena jalur akses tidak tersedia. Akibatnya, tata letak segitiga terbatas pada penggunaan shellside yang bersih. Untuk layanan yang memerlukan pembersihan mekanis pada bagian shell, pola persegi harus digunakan. Pembersihan bahan kimia tidak memerlukan jalur akses, sehingga tata letak segitiga dapat digunakan untuk layanan sisi shell yang kotor asalkan pembersihan bahan kimia sesuai dan efektif. Pola segitiga yang diputar jarang menawarkan keunggulan dibandingkan pola segitiga, dan akibatnya penggunaannya tidak begitu populer.

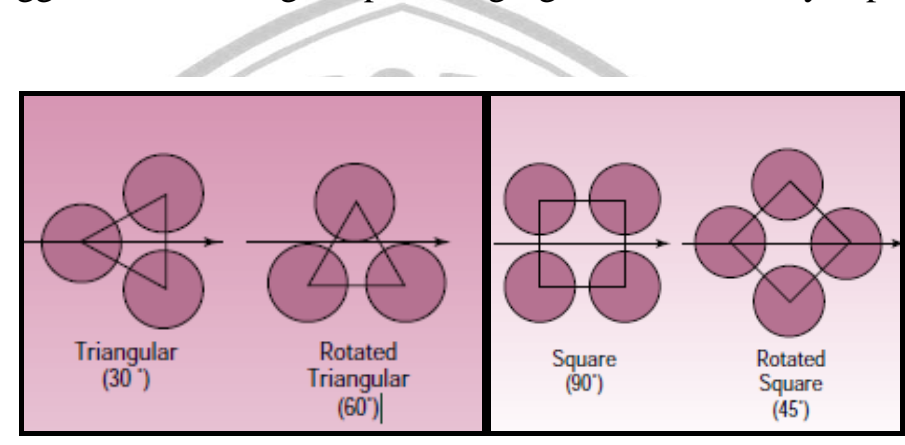

Gambar 8. Pola tata letak tube

Untuk kegunaan shellside kotor, tata letak tube persegi (square pitch) biasanya digunakan. Namun, karena ini adalah pola sejajar, ini menghasilkan turbulensi yang lebih/rendah. Jadi, jika bilangan Reynolds shellside rendah $(<2.000)$, biasanya menguntungkan untuk menggunakan pola persegi yang diputar (rotated square) karena ini menghasilkan turbulensi yang jauh lebih tinggi, yang menghasilkan efisiensi yang lebih tinggi dari konversi penurunan tekanan menjadi perpindahan panas. Seperti disebutkan sebelumnya, konstruksi tubesheet tetap biasanya digunakan untuk shellside bersih, kontruksi $U$-tube untuk penggunaan tubeside bersih, dan konstruksi kepala mengambang untuk penggunaan fluida kotor pada shellside dan tubeside. (Untuk layanan bersih pada shellside dan tubeide, baik konstruksi fixed-tubesheet atau U-tube, meskipun U-tube lebih disukai karena memungkinkan ekspansi diferensial antara shell dan tube.) Oleh karena itu, pola tube segitiga dapat digunakan. digunakan untuk penukar tubesheet tetap dan pola persegi (atau persegi yang diputar) untuk penukar kepala mengambang. Untuk penukar tube- $U$, pola berbentuk segitiga dapat digunakan asalkan aliran shellside bersih dan pola persegi (atau persegi yang diputar) dapat digunakan untuk aliran shellside jika kotor.

\section{PITCH TUBE}

Pitch tube didefinisikan sebagai jarak terpendek antara dua tube yang berdekatan. Untuk pola segitiga, TEMA menentukan jarak tube minimum 1,25 kali tube OD. Dengan demikian, tube OD $25 \mathrm{~mm}$ biasanya digunakan untuk tube $O D 20 \mathrm{~mm}$. Untuk pola persegi, TEMA juga merekomendasikan jalur pembersihan minimal 4 inci (atau $6 \mathrm{~mm}$ ) antara tube yang berdekatan. Jadi, jarak tube minimum untuk pola persegi adalah 1,25 kali $O D$ tube atau $O D$ tube ditambah $6 \mathrm{~mm}$, mana saja yang lebih 
besar. Misalnya, tube 20-mm harus diletakkan di atas pitch persegi 26-mm (20 $\mathrm{mm}+6 \mathrm{~mm})$, tetapi tube 25-mm harus diletakkan di atas pitch persegi 31,25-mm (25 mm x 1,25). (TEMA, 1999)

Desainer lebih suka menggunakan pitch tube minimum yang disarankan, karena mengarah ke diameter shell terkecil untuk sejumlah tube. Namun, dalam keadaan luar biasa, pitch tube dapat dinaikkan ke nilai yang lebih tinggi, misalnya, untuk mengurangi penurunan tekanan shellside. Ini terutama cocok dalam kasus shell aliran-silang. (Kern, 1950 dan Mukherjee, 1998)

\section{BAFFLES (PENYEKAT)}

Baffle digunakan untuk mendukung/menyangga tube, sehingga memungkinkan kecepatan yang diinginkan dipertahankan untuk fluida shellside, dan mencegah lepasnya tube karena getaran yang diinduksi aliran. Ada dua jenis buffle yaitu: jenis pelat dan batang. Baffle pelat mungkin berupa singgle-segmental, double-segmental, atau triple-segmental. Baffle dirancang untuk mengarahkan cairan shellside melintasi tubesheet seefisien mungkin. Memaksa cairan melewati bundle-tube pada akhirnya akan menyebabkan hilangnya tekanan. Jenis buffle yang paling umum adalah buffle segmental tunggal atau potongan yang ditunjukkan pada Gambar 9. yang mengubah arah aliran fluida shellside untuk mencapai aliran silang. Kekurangan dari buflle tersegmentasi termasuk potensi titik mati di exchanger dan getaran tube yang berlebihan. (Kern, 1950; Mukherjee, 1998 dan Charate, 2015)

\section{Jenis-jenis Buffles}

Baffle dapat diklasifikasikan sebagai tipe melintang dan membujur. Tujuan dari buffle longitudinal adalah untuk mengontrol arah aliran keseluruhan dari fluida shell sedemikian rupa sehingga pengaturan aliran keseluruhan yang diinginkan dari dua aliran fluida adalah tercapai. Misalnya, shell F, G, dan H memiliki sekat longitudinal. Baffle melintang dapat diklasifikasikan sebagai pelat sekat dan sekat kisi (batang, strip, dan aliran aksial lainnya). Baffle pelat digunakan untuk menopang tube selama perakitan dan operasi dan untuk mengarahkan cairan dalam bundel tube kira-kira pada sudut yang tepat ke tube untuk mencapai koefisien perpindahan panas yang lebih tinggi. Baffle pelat meningkatkan turbulensi cairan shell dan meminimalkan perbedaan suhu tube-to-tube dan tekanan termal karena aliran silang. Pilihan jenis buffle, jarak, dan buffle cut sangat ditentukan oleh laju aliran, laju perpindahan panas yang diinginkan, penurunan tekanan yang diizinkan, penyangga tube, dan getaran yang diinduksi aliran. Buffle disk dan donat / pelat pendukung digunakan terutama dalam penukar panas nuklir. Baflle batang (atau bar), jenis buffle kisi yang paling umum, digunakan untuk menopang tube dan meningkatkan turbulensi cairan shell. Aliran dalam penukar panas buffle batang sejajar dengan tube, dan getaran yang diinduksi aliran secara virtual dihilangkan dengan penyangga buffle tube. Salah satu alternatif penukar panas buffle batang adalah penggunaan tube bengkok. Tube bengkok memberikan kekakuan dan menghilangkan getaran tube yang diinduksi aliran, dapat dibersihkan dengan mudah di shellside dengan jet hidro, dan dapat dibersihkan dengan mudah di dalam tube, tetapi tidak dapat dipasang kembali. Penukar shell-and-tube baffle heliks dengan sekat seperti yang ditunjukkan pada Gambar 9. juga memiliki keuntungan sebagai berikut: penurunan tekanan shellside yang lebih rendah sambil mempertahankan koefisien perpindahan panas yang tinggi dari penukar segmental, mengurangi kebocoran dan menghilangkan titik mati dan zona resirkulasi (sehingga mengurangi fouling). Setiap penukar shell-and-tube memiliki sekat melintang kecuali untuk shell $\mathrm{X}$ dan $\mathrm{K}$, yang memiliki pelat penyangga karena satu-satunya tujuan dari sekat melintang ini adalah untuk menopang tube. (Charate, 2015 dan Nimankar, 2016) 


\section{Jarak Buffles}

Jarak buffle adalah jarak garis tengah ke garis tengah antara buffle yang berdekatan. Ini adalah parameter paling vital dalam desain Shell and Tube Heat Exchanger. Standar TEMA menentukan jarak sekat minimum sebagai seperlima dari diameter dalam shell atau 2 inci, mana saja yang lebih besar. Jarak yang lebih dekat akan mengakibatkan penetrasi bundel yang buruk oleh cairan shellside dan kesulitan dalam membersihkan sisi luar tube secara mekanis. Lebih lanjut, jarak sekat yang rendah menghasilkan distribusi aliran yang buruk.

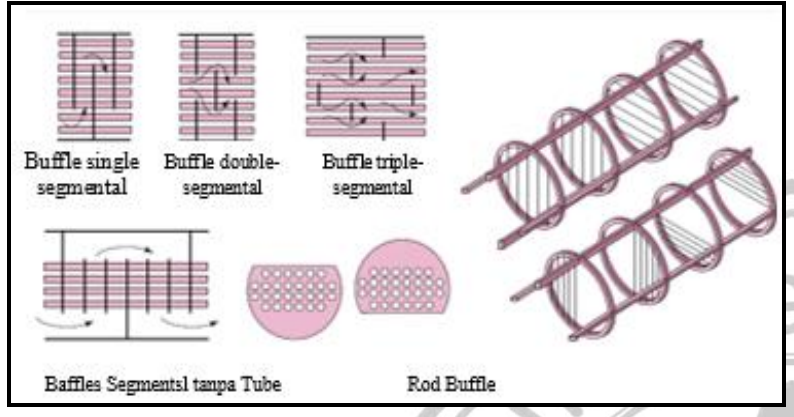

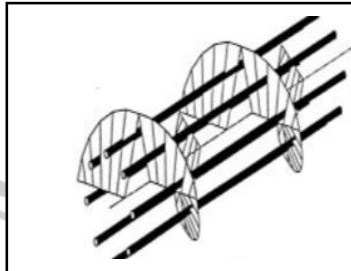

(a) Helix tunggal;

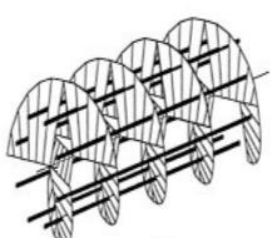

(b) Helix ganda.

\section{Gambar 9. Jenis Buffles}

Jarak buffle maksimum adalah diameter dalam shell. Jarak baffle yang lebih tinggi akan menyebabkan aliran yang didominasi longitudinal, yang kurang efisien dibandingkan aliran silang, dan bentang tube besar yang tidak didukung, yang akan membuat penukar rentan terhadap kegagalan tube karena getaran yang diinduksi oleh aliran. Jarak buffle yang optimal. Untuk aliran turbulen pada shellside $(R e>1.000)$, koefisien perpindahan panas bervariasi dengan 0,6-0,7 kekuatan kecepatan; namun, penurunan tekanan bervariasi pada daya 1,7-2,0. Untuk aliran laminar ( $R e<100$ ), eksponennya adalah 0,33 untuk koefisien perpindahan panas dan 1,0 untuk penurunan tekanan. Jadi, saat jarak buffle berkurang, penurunan tekanan meningkat pada tingkat yang jauh lebih cepat dari pada koefisien perpindahan panas. Ini berarti bahwa akan ada rasio optimum antara jarak baffle dengan diameter dalam shell yang akan menghasilkan efisiensi konversi penurunan tekanan menjadi perpindahan panas yang paling tinggi. Rasio optimal ini biasanya antara 0,3 dan 0,6. (Mukherjee, 1998)

\section{Potongan Baffle (Buffle cut)}

Seperti yang ditunjukkan pada Gambar 10, Potongan Baffle adalah ketinggian segmen yang dipotong di setiap baffle untuk memungkinkan fluida shellside mengalir melintasi baffle. Hal ini dinayatakan sebagai persentase dari diameter dalam shell. Meskipun ini juga merupakan parameter penting untuk desain Shell and Tube Heat Exchanger, efeknya kurang mendalam dibandingkan dengan baffle spacing. Potongan buffle dapat bervariasi antara $15 \%$ dan $45 \%$ dari diameter bagian dalam shell.

Baik potongan buffle yang sangat kecil maupun yang sangat besar menggangu efisiensi perpindahan panas pada shellside karena penyimpangan besar dari situasi ideal, seperti yang diilustrasikan pada Gambar 11. Sangat disarankan bahwa hanya potongan buffle antara 20\% dan 35\% yang digunakan. Mengurangi baffle cut di bawah $20 \%$ untuk meningkatkan koefisien perpindahan panas shellside atau meningkatkan baffle cut melebihi $35 \%$ untuk mengurangi penurunan tekanan shellside biasanya menyebabkan desain yang buruk. Aspek lain dari geometri bundel tube harus diubah untuk mencapai tujuan tersebut. Misalnya, buffle segmen ganda atau aliran shell terbagi, atau bahkan aliran shell silang, dapat digunakan untuk mengurangi penurunan tekanan shellside. Untuk fluida fase tunggal di shellside, potongan buffle horizontal seperti Gambar 10, dianjurkan, karena ini akumulasi endapan 
minimal di bagian bawah shell dan juga mencegah stratifikasi. Namun, dalam kasus shell dua jalur (TEMA F), potongan vertikal lebih disukai untuk kemudahan fabrikasi dan perakitan bundel. (Mukherjee, 1998)
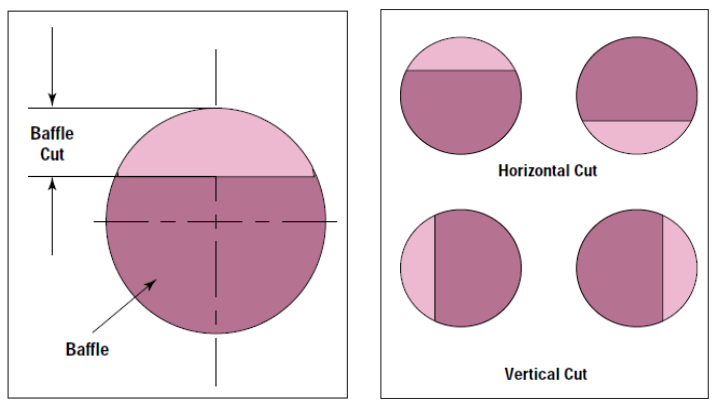

Gambar 10, Baffle Cut

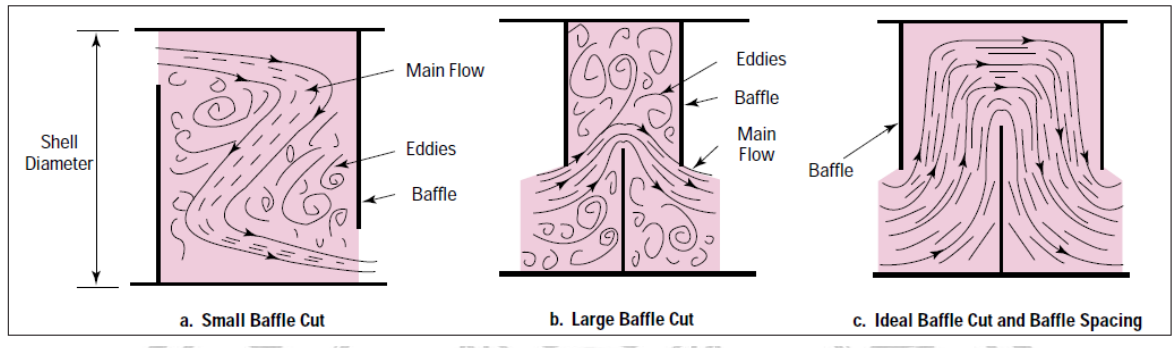

Gambar 11. Pengaruh besar kecilnya Potongan Buffle

\section{KECEPATAN ALIRANSILANG DAN KECEPATAN WINDOWS (BUFFLE CUT)}

Aliran melintasi tube disebut sebagai aliran silang, sedangkan aliran melalui buflle cut disebut aliran jendela (windows). Kecepatan jendela dan kecepatan aliran silang harus sedekat mungkin, sebaiknya dalam 20\%. Jika perbedaannya lebih dari itu, percepatan dan pertambahan berulang terjadi di sepanjang bundel tube, yang mengakibatkan konversi penurunan tekanan menjadi perpindahan panas yang tidak efisien.

\section{ANALISIS ALIRAN SHELLSIDE}

Pada shellside, tidak hanya ada satu aliran, tetapi aliran lintas-aliran utama dan empat aliran kebocoran atau aliran pintas, seperti yang diilustrasikan pada Gambar 12. Tinker mengusulkan penyebutan saluran ini yaitu saluran aliran-silang utama (B), aliran kebocoran tube-to-baffle-hole (A), aliran bypass bundel (C), aliran bypass melintasi partisi (F), dan aliran kebocoran pada baffle-shell (E). (Tinker, 1958).Sementara aliran B (aliran silang utama) sangat efektif untuk perpindahan panas, aliran lainnya tidak seefektif itu. Aliran A cukup efisien, karena fluida shellside bersentuhan dengan tube. Demikian pula, aliran $\mathrm{C}$ bersentuhan dengan sekeliling tube di sekitar bundel, dan aliran F bersentuhan dengan tube di sepanjang jalur partisi-lintasan. Akibatnya, aliran ini juga mengalami perpindahan panas, meskipun dengan efisiensi yang lebih rendah daripada aliran B. Namun, karena aliran E mengalir di sepanjang dinding shell, di mana tidak ada tube, dan tidak terjadi perpindahan panas sama sekali. Karena fraksi aliran sangat bergantung pada resistansi jalur, memvariasikan salah satu parameter konstruksi berikut akan mempengaruhi analisis aliran dan kinerja shellside dari exchanger; jarak baffle dan baffle cut; sudut tata letak tube dan jarak tube; jumlah jalur dalam arah aliran dan lebar jalur; jarak antara tube dan lubang buffle; jarak antara shell ID dan buffle; dan lokasi strip segel (sealing strips) dan batang segel (sealing rods). 


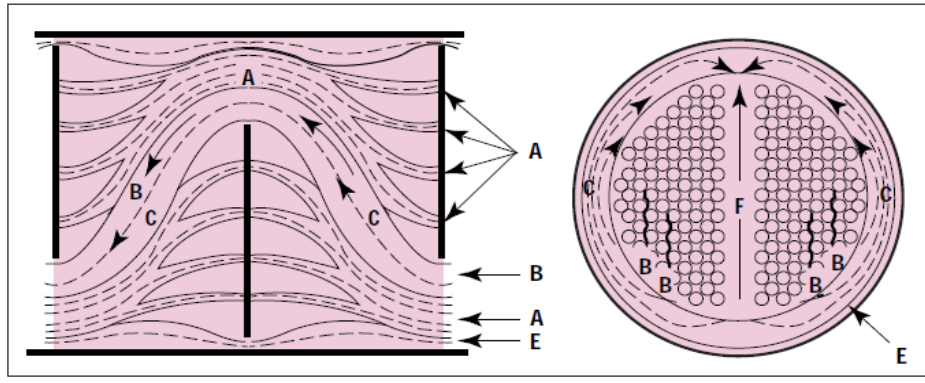

Gambar 12. Distribusi aliran pada Shellside

Menggunakan jarak buffle yang sangat rendah cenderung meningkatkan kebocoran dan aliran by pass. Ini karena kelima aliran shellside berada dalam posisi paralel dan, oleh karena itu, memiliki penurunan tekanan yang sama. Dimensi jalur kebocoran jalur diperbaiki. Akibatnya, saat jarak buffle dikurangi, resistansi jalur aliran melintang utama dan dengan demikian penurunan tekanannya meningkat. Karena penurunan tekanan dari kelima aliran harus sama, aliran kebocoran dan aliran bypass meningkat sampai pressure drop dari semua aliran seimbang. Hasil bersihnya adalah peningkatan penurunan tekanan tanpa peningkatan koefisien perpindahan panas yang sesuai. (Mukherjee, 1998)

\section{MEMPERKECIL PRESSURE DROP DENGAN MEMODIFIKASI DESAIN BUFFLE}

\section{Shell lintasan tunggal dan buffle segmen tunggal}

Alternatif buffle pertama adalah buffle segmental tunggal dalam shell satu jalur (TEMA E). Dalam banyak situasi, penurunan tekanan shellside terlalu tinggi dengan baffle segmental tunggal dalam shell single-pass, bahkan setelah meningkatkan jarak baffle dan baffle cut ke nilai tertinggi yang direkomendasikan. Situasi seperti itu dapat muncul saat menangani laju aliran shellside yang sangat tinggi atau ketika fluida shellside adalah gas bertekanan rendah. Dalam kasus ini, alternatif berikutnya yang harus diperhatikan adalah double segmental baffle, seperti ditunjukkan pada Gambar 9.

\section{Shell lintasan tunggal dan buffle segmen ganda}

Dengan mengubah buffle dari segmen tunggal menjadi segmen ganda pada jarak yang sama dalam penukar panas yang identik, kecepatan aliran silang berkurang kira - kira menjadi setengah, karena aliran shellside dibagi menjadi dua aliran paralel. Ini sangat mengurangi penurunan tekanan aliran silang. Namun, kecepatan jendela dan oleh karena itu penurunan tekanan jendela tidak dapat dikurangi secara berarti (dengan asumsi bahwa pemotongan buffle maksimum yang direkomendasikan sudah dicoba dengan segmen tunggal baffle sebelum beralih ke baffle segmen ganda). Namun demikian, karena penurunan tekanan aliran silang selalu jauh lebih besar daripada penurunan tekanan jendela, terjadi penurunan yang cukup berarti dalam penurunan tekanan total. Ada juga penurunan koefisien perpindahan panas shellside, tetapi ini jauh lebih kecil daripada penurunan pressure drop.

\section{Shell dengan Aliran Terbagi dan Baffle segmen Tunggal}

Jika penurunan tekanan shellside yang diijinkan tidak dapat dipenuhi bahkan dengan baffle segmental ganda pada jarak yang relatif besar, shell aliran terbagi (TEMA J) dengan baffle segmen tunggal, seperti ditunjukkan pada Gambar 1, harus diselidiki lebih lanjut. Karena penurunan tekanan 
sebanding dengan kuadrat kecepatan dan panjang lintasan, shell dengan aliran terbagi akan memiliki kira-kira seperdelapan penurunan tekanan dalam exchanger lintasan tunggal yang identik. Keuntungan dari shell aliran terbagi dibandingkan baffle segmental ganda adalah pada pengurangan penurunan tekanan yang lebih besar, karena tidak hanya kecepatan aliran silang tetapi bahkan kecepatan jendela dapat dikurangi. Kerugiannya adalah kenaikan biaya karena membutuhkan perpipaan tambahan.

\section{Shell Dengan Aliran Terbagi dan Buffle Segmen Ganda}

Jika shell aliran terbagi dengan baffle segmen tunggal tidak dapat memenuhi batas penurunan tekanan shellside yang diijinkan, maka perlu untuk mengadopsi kombinasi shell aliran terbagi dan sekat segmen ganda. Dengan kombinasi seperti itu, pengurangan yang sangat besar pada penurunan tekanan shellside dimungkinkan hingga serendah $4 \%$ dari penurunan tekanan dalam penukar jalur tunggal dengan jarak baffle dan potongan baffle yang sama. Dalam kontras yang tajam, koefisien perpindahan panas akan mengurangi sekitar $40 \%$.

\section{Buffle segmental tanpa tube di dalam jendela (window)}

Karena jarak baffle ditingkatkan untuk mengurangi penurunan tekanan shellside, exchanger menjadi lebih rentan terhadap kegagalan tube karena getaran yang diinduksi aliran. Exchanger dengan baffle segmen ganda lebih kecil kemungkinannya untuk mengalami masalah seperti itu dibandingkan dengan penukar dengan baffle segmen tunggal. Namun, masalah getaran dapat tetap ada bahkan dengan buffle segmen ganda. Dalam kasus seperti itu, desain tanpa-tube-dalam-jendela (Gambar 9) harus diadopsi. Di sini, setiap tube didukung oleh setiap buffle, sehingga rentang tube yang tidak didukung buffles. Dalam penukar dengan baffle segmental tunggal normal, rentang tube yang tidak didukung adalah dua kali jarak baffle.Jika perlu menggunakan jarak sekat yang sangat besar untuk membatasi penurunan tekanan shellside ke nilai yang diizinkan, penyangga antara dapat digunakan untuk meningkatkan frekuensi alami tube, sehingga menghasilkan desain yang aman terhadap kegagalan tube karena getaran aliran yang diinduksi. Desain no-tube-in-window membutuhkan diameter shell yang lebih besar untuk jumlah tube tertentu. Ini menaikkan biayanya, biasanya sekitar $10 \%$. Biaya yang lebih tinggi diimbangi sampai batas tertentu oleh koefisien perpindahan panas shellside yang lebih tinggi, karena aliran silang murni lebih efisien daripada kombinasi aliran silang dan aliran jendela dalam desain konvensional.

\section{Shell Aliran Silang}

Ada beberapa kegunaan yang batasan penurunan tekanannya begitu besar sehingga tidak ada konfigurasi shell/baffling di atas yang dapat menghasilkan desain yang memuaskan. Sebuah contoh kondensor ejektor uap yang beroperasi pada tekanan $50 \mathrm{~mm} \mathrm{Hg}$ dan memiliki penurunan tekanan yang diizinkan sebesar $5 \mathrm{~mm} \mathrm{Hg}$. Situasi seperti itu memerlukan penggunaan shell aliran silang (TEMA $\mathrm{X}$ ). Aliran silang murni terjadi dengan kecepatan yang sangat rendah, sehingga hampir tidak ada penurunan tekanan di shell. Penurunan tekanan yang terjadi hampir seluruhnya ada di nozel. Pelat penyangga akan diperlukan untuk memenuhi persyaratan TEMA dan mencegah kemungkinan getaran tube yang diinduksi aliran. Karena aliran shellside sejajar dengan pelat pendukung ini, penurunan tekanan shellside tidak meningkat. 


\section{MENINGKATKAN JARAK ANTAR TUBE (TUBE PITCH)}

Untuk sejumlah tube, semakin kecil jarak tube, semakin kecil diameter shell, dan oleh karena itu semakin rendah biayanya. Akibatnya, desainer cenderung mengemas sebanyak mungkin tube secara mekanis. (Mukherjee, 1998). Perancang umumnya mengatur jarak tube 1,25 kali tube OD. Untuk square pitch atau square pitch yang diputar, disarankan oleh TEMA untuk jalur pembersihan minimum 4 inci atau $6 \mathrm{~mm}$. Namun, dalam kasus selubung $\mathrm{X}$, mungkin perlu untuk meningkatkan tube pitch di atas TEMA minimum untuk memenuhi batasan penurunan tekanan, karena tidak ada parameter lain yang dapat dimodifikasi. Meningkatkan jarak tube untuk mengurangi penurunan tekanan umumnya tidak disarankan karena dua alasan. Pertama, ini meningkatkan diameter shell dan, dengan demikian, biayanya. Kedua, mengurangi penurunan tekanan dengan memodifikasi jarak baffle, baffle cut, atau tipe shell akan menghasilkan desain yang lebih murah. Terkait hidraulik termal, rasio tube-pitch terhadap diameter tube optimal untuk konversi penurunan tekanan menjadi perpindahan panas biasanya 1,25-1,35 untuk aliran turbulen dan sekitar 1,4 untuk aliran laminar.

\section{KESIMPULAN}

Heat exchanger adalah salah satu alat yang paling efisien untuk mentransfer panas dari satu fluida ke fluida lain. Jenis-jenis heat exchanger yang tersedia di pasar tergantung pada penggunaan dan aplikasi dilapangan. Parameter penting yang menjadipertimbangan designer heat exchanger adalah memperoleh koefisien perpindahan panas yang optimum dan presurre drop yang minimum serta menghasilkan design yang lebih murah. Beberapa variabel design yang menjadi pertimbangan designer yaitu; kegunaan dan konstruksi heat exchanger, design shellside dan tubeside, tata letak tube, pitch tube, bentuk dan jarak buffle, dan kecepatan aliran.

\section{DAFTAR PUSTAKA}

Andre L.H. Costa, A.L.H. and Queiroz, E.M. (2008). Design optimization of shell-and-tube heat exchangers. Applied Thermal Engineering 28, 1798-1805. https://www.sciencedirect.com/science/article/abs/pii/S1359431107003936

Charate, T., Awate, N., Badgujar, J., \& Jadhav, S. (2015). Review of Literature on Heat Transfer Enhancement in Heat Exchangers. International Journal of Scientific \& Engineering Research, Volume 6, (12), 198-201. https://www.ijser.org/researchpaper/Review-ofLiterature-on-Heat-Transfer-Enhancement-in-Heat-Exchangers.pdf.

Kern, D.Q. (1950). Process Heat Transfer. McGaw-Hill. Japan:Tokyo. 127-189. https://archive.org/details/.

Mukherjee, R. (1992). Use Double-Segmental Baffles in Shell-and-Tube Heat Exchangers. Chem. Eng. Progress, 88 (11), 47-52. https://pascal-francis.inist.fr/vibad/index.php?action=getRecordDetail\&idt=4421099.

Mukherjee, R. (1996). Don't Let Baffling Baffle You. Chem. Eng. Progress, 92 (4), 72-79. https://www.osti.gov/biblio/260813. 
Mukherjee, R. (1998). Effectively Design Shell-and-Tube Heat Exchangers. Chemical Engineering Progress. https://www.scribd.com/document/316714140/Effectively-Design-Shell-and-TubeHeat-Exchangers-pdf.

Nimankar, S. J., \& Dahake, P. S. K. (2016). Review of Heat Exchangers. Global Journal of Engineering Science and Researches. 3(12), 81-92. DOI- 10.5281/zenodo.223816. https://www.academia.edu/30973704/REVIEW_OF_HEAT_EXCHANGERS.

Samal, A.K. (2013). Shell and tube heat exchanger design using CFD tools. B.Tech Thesis on, Rotella, National Institute Technology. http://ethesis.nitrkl.ac.in/5259/1/109CH0458.pdf.

Tinker, T. (1958). Shellside Characteristics of Shell-and-tube Heat Exchangers: A Simplified Rating System for Commercial Heat Exchangers. Trans. ASME, 80, 36-52. https://www.coursehero.com/file/p1014rt/Tinker-T-1951-Shell-Side-Characteristics-of-Shelland-Tube-Heat-Exchangers/.

Tubular Exchanger Manufacturers Association. (1999). Standards of the Tubular Exchanger Manufacturers Association. 8th ed., Tarrytown, New York. https://funke.de/pdf/zertifikate/tema.pdf

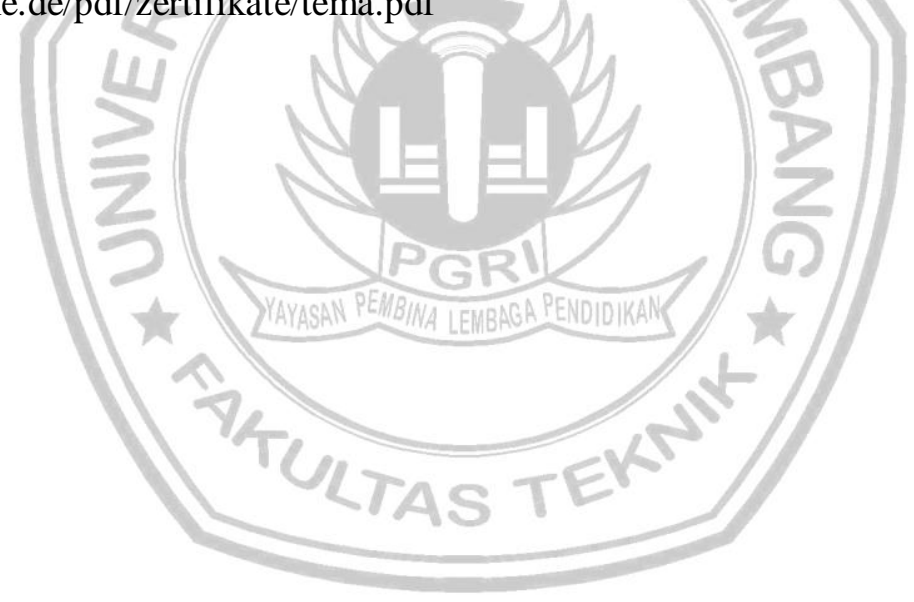

